\title{
Analisis Hubungan Antara Kelembaban Relatif Dengan Beberapa Variabel Iklim Dengan Pendekatan Korelasi Pearson Di Samudera Hindia
}

\author{
Miftahuddin",, Ananda Pratama1, Ichsan Setiawan² \\ ${ }^{1}$ Jurusan Statistika, FMIPA, Universitas Syiah Kuala, Banda Aceh \\ ${ }^{2}$ Jurusan Ilmu Kelautan, Fakultas FKP, Universitas Syiah Kuala, Banda Aceh, Indonesia \\ *Email korespondensi: miftah@unsyiah.ac.id
}

\begin{abstract}
Abstrak
Kelembaban relatif merupakan parameter yang dapat mempengaruhi perubahan iklim global termasuk di wilayah Indonesia. Provinsi Aceh terletak di Pulau Sumatera dan berada disekitar Selat Malaka untuk wilayah Aceh bagian utara dan timur, sedangkan berada disekitar Samudera Hindia untuk wilayah Aceh bagian barat dan selatan. Karena posisi geografis tersebut, Provinsi Aceh memiliki dampak yang cukup besar terhadap perubahan iklim. Perubahan kelembaban relatif akan menyebabkan terjadinya perubahan pada variabel iklim melalui siklus alamiah. Terdapat beberapa variabel iklim diantaranya suhu udara, curah hujan, suhu permukaan laut, kecepatan angin, radiasi matahari, dan ketinggian dinamis. Pada penelitian ini digunakan metode korelasi yang bertujuan untuk melihat keeratan hubungan setiap variabel iklim yang berasal dari Samudera Hindia. Berkaitan variabel iklim memiliki data kuantitatif maka metode Korelasi Pearson digunakan dalam penelitian ini. Hasil penelitian menunjukkan bahwa hubungan antara variabel suhu udara dan suhu permukaan laut memiliki hubungan keeratan tertinggi dengan nilai korelasi positif sebesar 0.769. Hubungan keeratan terendah yaitu variabel curah hujan dan kecepatan angin dengan nilai korelasi lemah negatif sebesar $\mathbf{- 0 . 0 1}$. Pada penelitian korelasi menunjukkan bahwa adanya gap dalam dataset menurunkan nilai besaran korelasi positif. Nilai korelasi dengan gap memiliki kecenderungan memiliki nilai koefisien korelasi lebih rendah dibandingkan nilai korelasi tanpa gap dalam dataset untuk korelasi positif. Sedangkan untuk korelasi negatif berlaku sebaliknya. Adanya gap dapat mempengaruhi pola distribusi, bentuk dan kemencengan distribusi data sehingga mempengaruhi besaran korelasi dan arah (positif atau negatif).
\end{abstract}

Kata kunci: Kelembaban Relatif, Korelasi Pearson, Variabel Iklim, Samudera Hindia, Gap data

\begin{abstract}
Relative humidity is a parameter that can affect global climate change, including in Indonesia region. Aceh province is located on the island of Sumatra and is located around the Malacca Strait in the northern and eastern parts of Aceh, while it is located around the Indian Ocean for the western and southern parts of Aceh. Thus, due to its geographic position Aceh Province has a considerable impact on climate change. Changes in relative humidity will cause changes in climate variables through natural cycles. There are several climate variables including air temperature, rainfall, sea surface temperature, wind speed, solar radiation, and dynamic altitude. In this study, the correlation method is used which aims to see the closeness of the relationship between each climate variable from in the Indian Ocean. Regarding climate variables having quantitative data, the Pearson Correlation method is used in this study. The results showed that the relationship between the variables air temperature and sea surface temperature had the highest relationship with a positive correlation value of 0.769 . The lowest relationship is the variable rainfall and wind speed with a negative weak correlation value of $\mathbf{- 0 . 0 1}$. In correlation research, it shows that a gap in the dataset reduces the value of the positive correlation magnitude. The correlation value with gap tends to have a lower correlation coefficient value than the gapless correlation value in the dataset for positive correlation. Meanwhile, negative correlation applies the opposite. The existence of gaps can affect the distribution pattern, shape and slope of the data distribution so that it affects the correlation magnitude and direction (positive or negative).
\end{abstract}

Keywords: relative humidity, Pearson correlation, climate variable, Indian Ocean, data gap 


\section{Pendahuluan}

Perubahan iklim merupakan tantangan masa depan yang dapat dirasakan dampaknya sangat luas. Hal ini dapat dirasakan adanya pemanasan global (global warming) yang semakin meningkat, salah satu efeknya berupa perubahan iklim (climate change). Interaksi variabel iklim yang berasal dari darat, laut dan atmosfer merupakan bagian dari sistem perubahan iklim bumi. Lautan sangat mempengaruhi iklim sehingga mempengaruhi pola aktivitas kehidupan manusia, tidak hanya aktivitas yang langsung bersinggungan dengan laut, tetapi juga aktivitas dalam kehidupan di daratan dan udara. Kondisi ini dimungkinkan karena luas lautan di dunia mencapai $71 \%$ [1, 2].

Pada penelitian variabel iklim telah kami mulai sejak 2006 dengan mengamati fenomena ENSO melalui wavelet morlet [3], regresi dan deret waktu pada tahun 2007 [4]. Iklim bumi senantiasa mengalami perubahan, dimana perubahan iklim di masa lampau memiliki kecenderungan berlangsung secara alamiah. Hal ini disebabkan oleh belum berkembangnya kemajuan IPTEK seperti revolusi industri saat ini. Selanjutnya penelitian dalam identifikasi fitur iklim dilakukan pada tahun 2014 dengan menggunakan pendekatan korelasi kanonik [5]. Sementara itu, variabilitas iklim dan sirkulasi di Samudera Hindia juga telah diteliti oleh Schot [6] yang memfokuskan beragam waktu seperti, antar musiman (interseasonal), antar tahunan (interannual), dan skala waktu yang lebih panjang (decadal).

Menurut laporan IPCC (2007) bahwa sejak tahun 1961 hingga 1993, permukaan laut dunia telah mengalami kenaikan dengan laju rata-rata 1,8 mm/tahun. Menurut laporan ke-6 tahun 2020 dari IPCC bahwa sejak dari 60 tahun yang lalu perubahan iklim (climate change) yang terjadi sampai saat ini sangat berkaitan erat dengan aktivitas manusia, sehingga sifat kejadian dan laju perubahan menjadi lebih cepat dan drastis [7, 8]. Meningkatnya jumlah penduduk dunia hampir di semua negara, berkembangnya era revolusi industri dari 1.0 ke 4.0 di perkotaan hingga pedesaan, adanya gas emisi dari kendaraan transportasi, mobilitas penduduk yang tinggi, dan produk elektronik lainnya, serta tingkah laku manusia (behavior and life style), adanya pembakaran hutan dan hot spot saat musim kemarau merupakan pemicu dari perubahan kualitas variabel iklim.

Salah satu fitur iklim yang berpengaruh terhadap perubahan iklim adalah kelembaban (relatif maupun mutlak). Di daerah perkotaan sumber kelembaban berasal dari air hujan yang saat ini cenderung menjadi genangan air diakibatkan adanya permukaan padat seperti semen, beton, parit, selokan, dan pipa-pipa drainase. Sedangkan di daerah pedesaan sebagian besar air hujan meresap ke dalam tanah dan menjadi sumber terjadinya penguapan sehingga cenderung menyejukkan udara sekitar. Perubahan iklim dipermukaan bumi sangat berkaitan satu dengan yang lain. Kelembaban relatif merupakan salah satu faktor yang mempengaruhi perubahan iklim tersebut. Perubahan pada kelembaban relatif akan menyebabkan terjadinya perubahan pada unsur-unsur iklim lainnya seperti suhu udara, curah hujan, kecepatan angin, radiasi matahari, suhu permukaan laut, dan lain-lain [5, 7, 8]. Posisi Aceh yang juga berada antara lintasan Selat Malaka dan sekitar Samudera Hindia yang dipengaruhi oleh kedua sirkulasi iklim di kedua wilayah tersebut. Oleh karena itu, dalam penelitian ini perlu dilakukan analisis untuk mengetahui hubungan antara kelembaban relatif terhadap unsur-unsur iklim di Samudera Hindia dengan dan tanpa gap pada dataset. Pendekatan yang digunakan melalui uji statistika untuk mengukur keeratan hubungan antara dua variabel yang disebut analisis korelasi (correlation analysis). Sedangkan, ukuran untuk menentukan kuatnya atau derajat keeratan hubungan antar dua variabel dinamakan koefisien korelasi (the correlation coefficient).

\section{Metode Penelitian}

\subsection{Dataset}

Data yang digunakan dalam penelitian ini adalah data harian dari tahun 2006 sampai dengan tahun 2018. Data tersebut diperoleh dari National Oceanic and Atmospheric Administration (NOAA) atau dapat diakses melalui website Global Tropical Moored Buoy Array. Data yang digunakan yaitu data harian dengan posisi titik $4^{\circ} \mathrm{N} 90^{\circ} \mathrm{E}$ yaitu satu titik yang dekat dengan wilayah Provinsi Aceh. Adapun variabel yang digunakan adalah kelembaban relatif $(\%)$, suhu udara $\left({ }^{\circ} \mathrm{C}\right)$, curah hujan $(\mathrm{mm} / \mathrm{hr})$, kecepatan angin $(\mathrm{m} / \mathrm{s})$, radiasi matahari gelombang pendek $\left(\mathrm{w} / \mathrm{m}^{2}\right)$, suhu permukaan laut $\left({ }^{\circ} \mathrm{C}\right)$, dan ketinggian dinamis $\left(\mathrm{w} / \mathrm{m}^{2}\right)$.

\subsection{Korelasi Pearson}

Metode yang digunakan dalam penelitian ini adalah analisis korelasi, yaitu metode statistika yang digunakan untuk menentukan suatu besaran yang menyatakan bagaimana kuat lemahnya hubungan antara suatu variabel dengan variabel lain dengan tidak mempersoalkan apakah suatu variabel tertentu tergantung kepada variabel lain [9]. Semakin nyata hubungan linier maka semakin kuat atau tinggi derajat hubungan garis lurus antara kedua variabel tersebut. Terdapat beberapa teknik korelasi yang sangat populer sampai sekarang seperti Korelasi Pearson Product Moment, Korelasi Rank Spearman, Korelasi Parsial, Korelasi Kontingensi, Korelasi Eta, Korelasi Kendall's Tau, Korelasi Point Serial (Tunggal), Korelasi Biserial (Ganda), dan Korelasi Liliefors. 
Korelasi Pearson merupakan korelasi sederhana yang hanya melibatkan satu variabel terikat (dependent) dan satu variabel bebas (independent). Korelasi Pearson menghasilkan koefesien korelasi yang berfungsi untuk mengukur kekuatan hubungan linier antara dua variabel [9]. Menurut Conover [10] korelasi Pearson digunakan untuk mengetahui tingkat atau keeratan hubungan antara dua variabel atau dua fitur objek. Besarnya nilai korelasi Pearson dapat dilihat pada persamaan berikut:

$$
r_{x y}=\frac{n \sum x y-\left(\sum x\right)\left(\sum y\right)}{\sqrt{\left[n \sum x^{2}-\left(\sum x\right)^{2}\right]\left[n \sum y^{2}-\left(\sum y\right)^{2}\right]}}
$$

dimana: $x$ : variabel pertama, $y$ : variabel kedua dan $n$ : banyaknya pengamatan

Koefisien korelasi adalah ukuran yang dipakai untuk mengetahui derajat hubungan antara variabel-variabel. Nilai koefesien korelasi berada di antara negatif 1 sampai positif 1 yaitu dapat dilihat pada Tabel 1 berikut:

Tabel 1. Kriteria Korelasi Pearson

\begin{tabular}{ccl}
\hline No & Nilai $\mathbf{r}$ & \multicolumn{1}{c}{ Interpretasi } \\
\hline 1 & $0.00-0.199$ & Sangat Rendah \\
2 & $0.20-0.399$ & Rendah \\
3 & $0.40-0.599$ & Sedang \\
4 & $0.60-0.799$ & Kuat \\
5 & $0.80-1.000$ & Sangat Kuat \\
\hline
\end{tabular}

Hubungan antara dua variabel linier sempurna, bila sebaran data tersebut akan membentuk garis lurus. Sekalipun demikian pada kenyataannya tidak mudah mendapatkan atau menemukan data yang dapat membentuk garis linier sempurna [9].

\subsection{Asumsi Uji Korelasi}

Sebelum implementasi untuk mengetahui hubungan antar variabel, dilakukan uji Korelasi terlebih dahulu yang memenuhi serangkaian asumsi. Asumsi-asumsi uji Korelasi tersebut adalah:

1. Uji Normalitas, dimana sebaran variabel-variabel yang hendak dikorelasikan berdistribusi normal.

2. Uji Linieritas, dimana hubungan antara dua variabel harus linier. Misalnya ditunjukkan melalui straightline.

3. Uji Ordinalitas, dimana variabel harus diukur dengan minimal skala ordinal.

4. Uji Homoskedastisitas, dimana variabilitas skor di variabel Y harus tetap konstan di semua nilai variabel $\mathrm{X}$

Uji normalitas dapat dilakukan menggunakan uji Shapiro-Wilk, uji Liliefors, uji Jarque-Bera, Shapiro-Francia, atau Anderson-Darling

\section{Hasil dan Pembahasan}

\subsection{Plot Time Series}

Langkah awal mengeksplorasi data yang dilakukan dalam penelitian ini adalah membuat plot time series dari semua variabel penelitian seperti yang dapat dilihat pada Gambar 1 berikut:

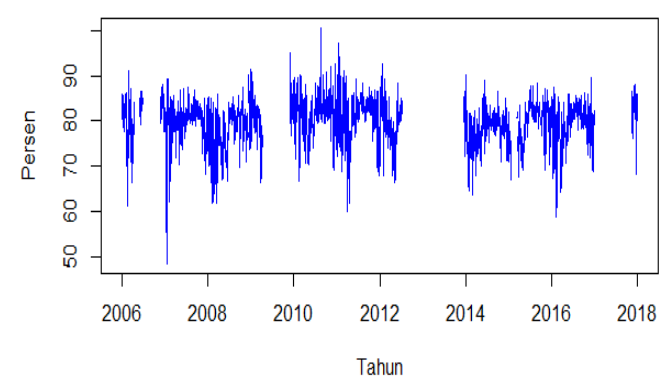

(a) kelembaban relatif

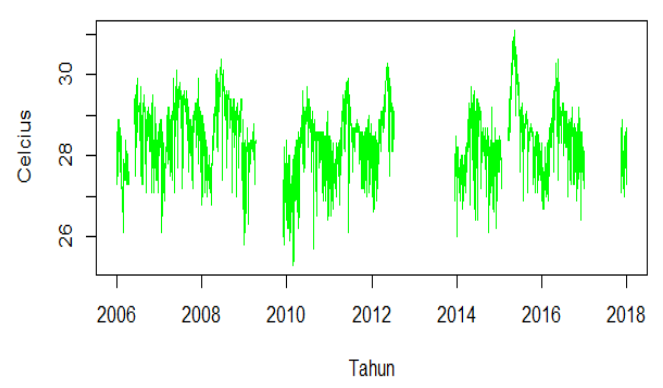

(b) suhu udara 


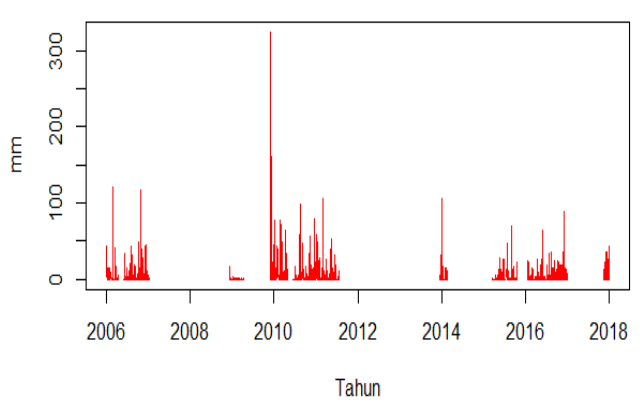

(c) curah hujan

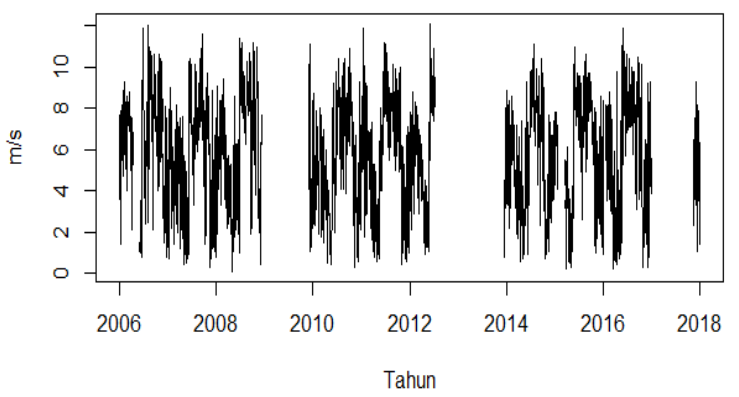

(e) kecepatan angin

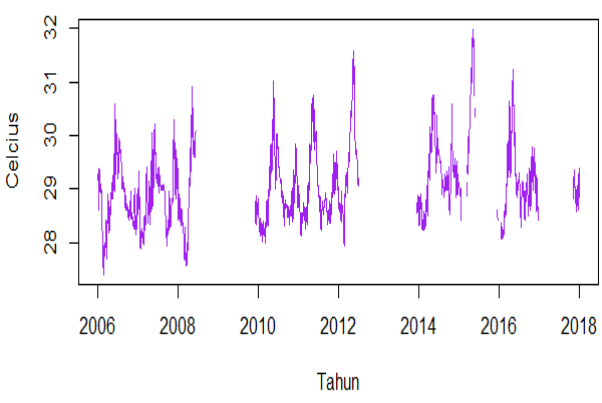

(d) suhu permukaan laut

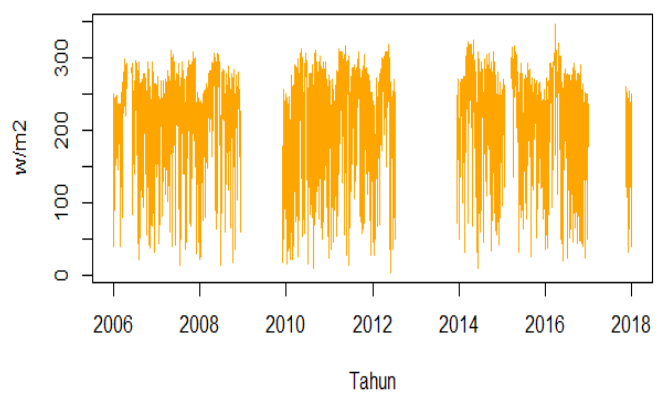

(f) radiasi surya gelombang pendek

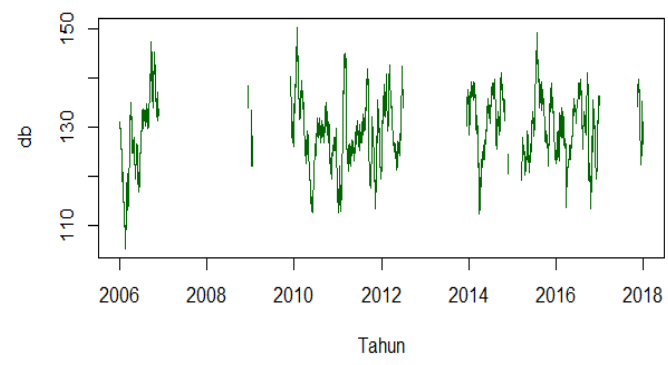

(g) ketinggian dinamis

\section{Gambar 1 Pola data dari setiap variabel}

Gambar 1 menunjukkan bahwa setiap variabel memiliki pola yang berbeda-beda dan juga memiliki variabilitas data gap yang berbeda-beda. Kelembaban relatif (Y) di Samudera Hindia setiap harinya terlihat adanya pola musiman seperti pada gambar (a) pada pola data kelembaban relatif yang berada disekitar rata-rata hanya terdapat beberapa data yang mengalami kenaikan dan penurunan. Suhu udara $\left(\mathrm{X}_{1}\right)$ di Samudera Hindia terlihat adanya musiman seperti pada gambar b pada pola data suhu udara hanya ada beberapa hari yang terlihat memiliki pola yang menurun dan meningkat disekitar rata-rat $28^{\circ} \mathrm{C}$. Curah hujan $\left(\mathrm{X}_{2}\right)$ di Samudera Hindia setiap harinya terlihat pola yang menaik dan turun dan tidak beraturan seperti pada gambar (c) pada pola data curah hujan. Pola data curah hujan menunjukkan adanya data ekstrim. Suhu permukaan laut $\left(\mathrm{X}_{3}\right)$ di Samudera Hindia setiap harinya terlihat seperti adanya pola musiman yang terdapat pada plot seperti pada gambar (d). Kecepatan angin $\left(\mathrm{X}_{4}\right)$ di Samudera Hindia setiap harinya terlihat adanya pola musiman seperti pada gambar (e) pada pola data kecepatan angin hanya ada beberapa hari yang mengalami peningkatan dan seperti terlihat adanya pola musiman. Radiasi surya gelombang pendek $\left(\mathrm{X}_{5}\right)$ di Samudera Hindia setiap harinya terlihat adanya pola naik turun seperti pada gambar (f) namun terdapat pola musiman pada data tersebut. Ketinggian dinamis $\left(\mathrm{X}_{6}\right)$ di Samudera Hindia setiap harinya terlihat adanya pola musiman seperti pada gambar (g) pada pola data ketinggian dinamis hanya ada beberapa data yang mengalami kenaikan dan penurunan. Berdasarkan Gambar 1 dapat dilihat bahwa setiap plot masing-masing variabel memiliki gap atau data hilang yang berbeda-beda. 
Tabel 2 berikut menyajikan data hilang untuk setiap variabel.

Tabel 2 Ringkasan data hilang untuk setiap variabel

\begin{tabular}{clc}
\hline Variabel & \multicolumn{1}{c}{ Tahun } & Missing Value \\
\hline $\mathrm{Y}$ & 2007, 2009, 2013, dan 2017. & 1346 \\
$\mathrm{X}_{1}$ & 2009, 2013, dan 2017. & 1194 \\
$\mathrm{X}_{2}$ & $2007-2009,2012-2013$, dan 2017 & 2759 \\
$\mathrm{X}_{3}$ & $2009,2013,2015$, dan 2017 & 1685 \\
$\mathrm{X}_{4}$ & 2009, 2013, dan 2017 & 1326 \\
$\mathrm{X}_{5}$ & 2009, 2013, dan 2017 & 1309 \\
$\mathrm{X}_{6}$ & 2007-2009, 2013, 2015, dan 2017 & 2097 \\
\hline
\end{tabular}

Berdasarkan Tabel 2 dapat dilihat bahwa setiap variabel memilki gap atau data hilang yang berbeda-beda. Namun pada tahun 2009, 2013, dan 2017 dari setiap variabel terdapat gap atau data hilang. Hal ini disebabkan oleh beragam sebab seperti: kurangnya kontrol alat pada setiap pengukuran, baterai (power) untuk merecord data habis, cuaca buruk adanya badai atau gelombang pasang laut yang menyebabkan sulitnya alat merecord data secara otomatis, adanya hambatan teknis, dan penyebab lainnya sehingga mempengaruhi record data yang dihasilkan.

\subsection{Ringkasan Statistik}

Ringkasan statistik dapat memberikan informasi statistic dari variabel-vaeriabel iklim yang digunakan seperti: berupa nilai minimum, quartil 1, median, mean, quartil 3, nilai maksimum, dan lain-lain. Berikut ini merupakan tabel ringkasan statistik variabel yang digunakan dalam penelitian:

Tabel 3 Ringkasan statistik variabel observasi

\begin{tabular}{crrrrrrrrr}
\hline \multirow{2}{*}{ Variabel } & \multirow{2}{*}{ Min } & \multirow{2}{*}{ Kuartil 1 } & \multirow{2}{*}{ Median } & Mean & $\begin{array}{c}\text { Kuartil } \\
\text { III }\end{array}$ & Max & Range & Variansi & $\begin{array}{c}\text { Standar } \\
\text { Deviasi }\end{array}$ \\
\hline Y & 48.5 & 77.1 & 80.5 & 79.74 & 82.7 & 100.5 & 52.0 & 23.172 & 4.814 \\
$\mathrm{X}_{1}$ & 25.3 & 27.9 & 28.5 & 28.46 & 29.0 & 31.1 & 5.8 & 0.636 & 0.797 \\
$\mathrm{X}_{2}$ & 0.0 & 0.0 & 0.24 & 4.506 & 2.4 & 324.0 & 320.0 & 0.326 & 0.571 \\
$\mathrm{X}_{3}$ & 27.4 & 28.6 & 28.95 & 29.06 & 29.4 & 31.98 & 4.57 & 0.505 & 0.710 \\
$\mathrm{X}_{4}$ & 0.1 & 3.9 & 6.0 & 5.856 & 7.8 & 12.1 & 12.0 & 6.549 & 2.559 \\
$\mathrm{X}_{5}$ & 5.3 & 181.5 & 235.9 & 216.5 & 266.5 & 345.5 & 340.2 & 4589.892 & 67.748 \\
$\mathrm{X}_{6}$ & 105.4 & 124.7 & 129.4 & 129.3 & 134.2 & 150.3 & 44.9 & 48.542 & 6.967 \\
\hline
\end{tabular}

Berdasarkan Tabel 3 diketahui bahwa nilai kelembaban relatif (Y) minimum adalah sebesar 48.50\% dan nilai maksimum adalah sebesar $100.50 \%$, dapat dikatakan pada amatan tersebut terjadi data ekstrim yang mengalami kelembaban maksimum. Suhu udara $\left(\mathrm{X}_{1}\right)$ minimum adalah sebesar $25.3{ }^{\circ} \mathrm{C}$ dan suhu udara maksimum mencapai $31.1^{\circ} \mathrm{C}$ dengan rata-rata suhu udara $28.46^{\circ} \mathrm{C}$. Curah hujan $\left(\mathrm{X}_{2}\right)$ minimum adalah sebesar $0.0 \mathrm{~mm}$ (tidak terjadi hujan) dan curah hujan maksimum mencapai $324.0 \mathrm{~mm}$ dan memiliki range yang sangat jauh, dan dapat dikatakan bahwa pada curah hujan maksimum terjadi curah hujan ekstrim. Suhu permukaan laut $\left(\mathrm{X}_{3}\right)$ minimum adalah sebesar $27.41{ }^{\circ} \mathrm{C}$ dan suhu permukaan laut maksimum mencapai $31.98^{\circ} \mathrm{C}$ dengan rata-rata suhu permukaan laut sebesar $29.06^{\circ} \mathrm{C}$. Kecepatan angin $\left(\mathrm{X}_{4}\right)$ minimum adalah sebesar $0.10 \mathrm{~m} / \mathrm{s}$ dan kecepatan angin maksimum mencapai $12.1 \mathrm{~m} / \mathrm{s}$ dengan rata-rata kecepatan angin sebesar $5.856 \mathrm{~m} / \mathrm{s}$. Radiasi matahari $\left(\mathrm{X}_{5}\right)$ minimum adalah sebesar $5.3 \mathrm{w} / \mathrm{m}^{2}$ dan radiasi matahari tertinggi mencapai $345.5 \mathrm{w} / \mathrm{m}^{2}$, pada data radiasi matahari gelombang pendek terlihat adanya data ekstrim disebabkan oleh jauhnya range data minimum dan maksimum. Ketinggian dinamis $\left(\mathrm{X}_{6}\right)$ minimum adalah sebesar $105.4 \mathrm{db}$ dan ketinggian dinamis maksimum sebesar $150.3 \mathrm{db}$ dengan ratarata $129.3 \mathrm{db}$.

\subsection{Scatterplot Matrix}

Scatterplot Matrix memberikan informasi tentang pola hubungan, bentuk distribusi, dan korelasi antara variabel respon dan variabel prediktor maupun antar variabel prediktor. Berikut ini merupakan gambar scatterplot matrix yang bertujuan untuk melihat histogram, korelasi, serta garis regresi dari data yang digunakan dalam penelitian. 


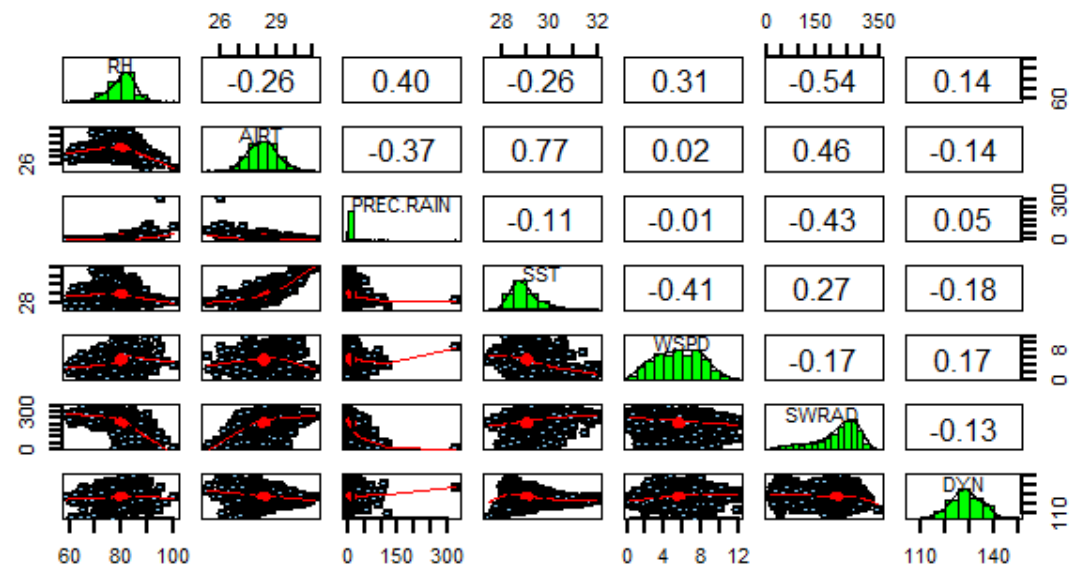

Gambar 2 Scatterplot Matrix

Gambar 2 merupakan scatterplot matrix yaitu untuk memberikan informasi tentang pola hubungan, bentuk distribusi, dan korelasi baik antara variabel prediktor dan variabel respon maupun antar variabel prediktor. Berdasarkan gambar tersebut menunjukkan bahwa terdapat dua variabel penelitian yang memiliki bentuk histogram simetris, sedangkan lima lainnya tidak simetris. Variabel yang memiliki bentuk histogram simetris adalah $\mathrm{X}_{1}$ (suhu udara) dan $\mathrm{X}_{6}$ (ketinggian dinamis) sedangkan variabel dengan bentuk histogram tidak simetris adalah $\mathrm{Y}$ (kelembaban relatif) yaitu menjulur ke kiri, $\mathrm{X}_{2}$ (curah hujan) yaitu menjulur ke kanan, $\mathrm{X}_{3}$ (suhu permukaan laut) yaitu menjulur ke kanan, $\mathrm{X}_{4}$ (kecepatan angin) yaitu menjulur ke kanan dan $\mathrm{X}_{5}$ (radiasi matahari gelombang pendek) yaitu menjulur ke kiri. Variabel $\mathrm{X}_{1}$ (suhu udara) dan $\mathrm{X}_{6}$ (ketinggian dinamis) memiliki bentuk histogram yang mirip dengan distribusi normal. Oleh karena itu, secara visual variabel $\mathrm{X}_{1}$ dan $\mathrm{X}_{6}$ dapat dikatakan berdistribusi normal.

Korelasi pada scatterplot matrix di atas merupakan korelasi pearson yaitu untuk mengetahui pola hubungan antara variabel respon (Y) dengan semua variabel prediktor (X) dan juga antara variabel prediktor. Berdasarkan nilai korelasi pada scatterplot matrix tersebut dapat dilihat bahwa variabel $\mathrm{X}_{1}$ (suhu udara) dan $\mathrm{X}_{3}$ (suhu permukaan laut) memiliki hubungan keeratan tertinggi dibandingkan dengan variabel lainnya, baik itu secara hubungan antara variabel respon dengan variabel bebas, maupun secara keseluruhan dengan nilai korelasi positif sebesar 0.77. Kemudian untuk nilai korelasi terendah berada pada $\mathrm{X}_{2}$ (curah hujan) dan $\mathrm{X}_{4}$ (kecepatan angin) dengan nilai korelasi negatif sebesar -0.01 . Pada gambar juga terdapat beberapa variabel yang berpola linier dan berkorelasi kuat positif yaitu variabel $\mathrm{X}_{1}$ dan $\mathrm{X}_{5}$, variabel $\mathrm{Y}$ dan $\mathrm{X}_{2}$ dengan nilai korelasi berturut-turut adalah sebesar 0.46 dan 0.40 . Hal ini berarti semakin besar $\mathrm{X}_{2}$ (suhu udara) maka semakin besar $\mathrm{X}_{5}$ (radiasi matahari gelombang pendek) begitu juga semakin besar $\mathrm{Y}$ (kelembaban relatif) maka semakin besar $\mathrm{X}_{2}$ (curah hujan). Selain itu, terdapat juga variabel yang berkorelasi kuat negatif yaitu variabel $\mathrm{Y}$ dan $\mathrm{X}_{5}, \mathrm{X}_{2}$ dan $\mathrm{X}_{5}, \mathrm{X}_{3}$ dan $\mathrm{X}_{4}$ dengan nilai korelasi berturut-turut sebesar -0.54, -0.43 dan -0.41 . Hal ini berarti bahwa semakin besar $\mathrm{Y}$ (kelembaban relatif) maka semakin rendah $\mathrm{X}_{5}$ (radiasi matahari) begitu juga dengan $\mathrm{X}_{2}$ (curah hujan) dan $\mathrm{X}_{5}$ (radiasi matahari gelombang pendek) serta $\mathrm{X}_{3}$ (suhu permukaan laut) dan $\mathrm{X}_{4}$ (kecepatan angin).

Tabel 4 Uji Normalitas dari variabel observasi

\begin{tabular}{crrrcr}
\hline Variabel & Skewness & $\begin{array}{c}\text { Shapiro-Wilk } \\
\text { normality test }(\mathrm{W})\end{array}$ & p-value & $\begin{array}{c}\text { Anderson- } \\
\text { Darling test }(\mathrm{A})\end{array}$ & p-value \\
\hline $\mathrm{Y}$ & -0.719614 & 0.96599 & $<2.2 \mathrm{e}-16$ & 31.568 & $<2.2 \mathrm{e}-16$ \\
$\mathrm{X}_{1}$ & -0.109593 & 0.99713 & $8.797 \mathrm{e}-06$ & 3.2381 & $4.133 \mathrm{e}-08$ \\
$\mathrm{X}_{2}$ & 10.3042 & 0.34505 & $<2.2 \mathrm{e}-16$ & 336.26 & $<2.2 \mathrm{e}-16$ \\
$\mathrm{X}_{3}$ & 1.01938 & 0.94468 & $<2.2 \mathrm{e}-16$ & 38.355 & $<2.2 \mathrm{e}-16$ \\
$\mathrm{X}_{4}$ & -0.132658 & 0.98287 & $<2.2 \mathrm{e}-16$ & 13.263 & $<2.2 \mathrm{e}-16$ \\
$\mathrm{X}_{5}$ & -0.986792 & 0.91168 & $<2.2 \mathrm{e}-16$ & 90.248 & $<2.2 \mathrm{e}-16$ \\
$\mathrm{X}_{6}$ & -0.153996 & 0.99762 & 0.001281 & 1.1157 & 0.006378 \\
\hline
\end{tabular}

Uji normalitas dalam perhitungan statistik dataset kelembaban relatif adalah menguji Hipotesa:

- $\mathrm{H}_{0}$ : Data kelembaban relatif berdistribusi Normal

- $\mathrm{H}_{1}$ : Data kelembaban relatif tidak berdistribusi Normal 
Kemudian dengan melihat $p$-value pada hasil perhitungannya dengan ketentuan bahwa:

- Bila $p$-value $<0.05$ maka $\mathrm{H}_{0}$ ditolak, berarti data kelembaban tidak berdistribusi normal

- $\quad$ Bila $p$-value $>0.05$ maka $\mathrm{H}_{0}$ diterima, berarti data kelembaban berdistribusi normal

Dari Tabel 4 terlihat bahwa semua variabel memiliki $p$-value $<0.05$ maka $\mathrm{H}_{0}$ Ditolak, berarti data kelembaban tidak berdistribusi normal, demikian pula dengan variabel lainnya.
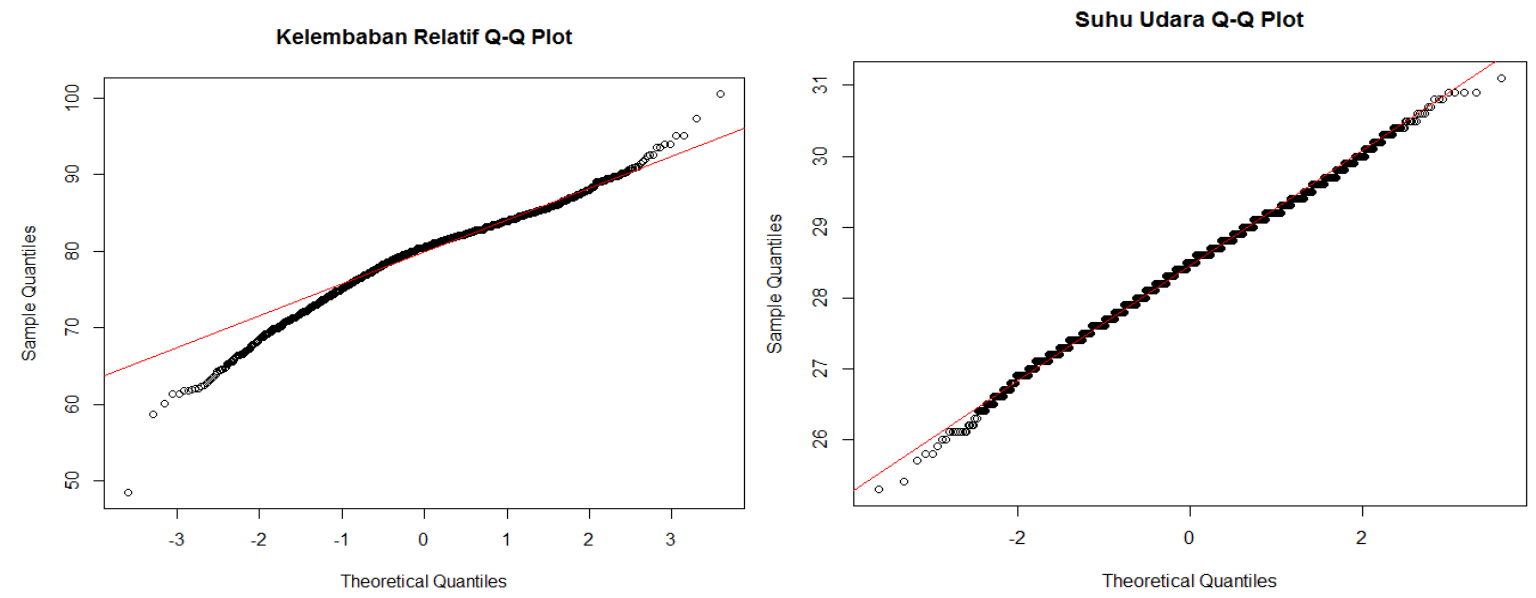

Curah Hujan Q-Q Plot
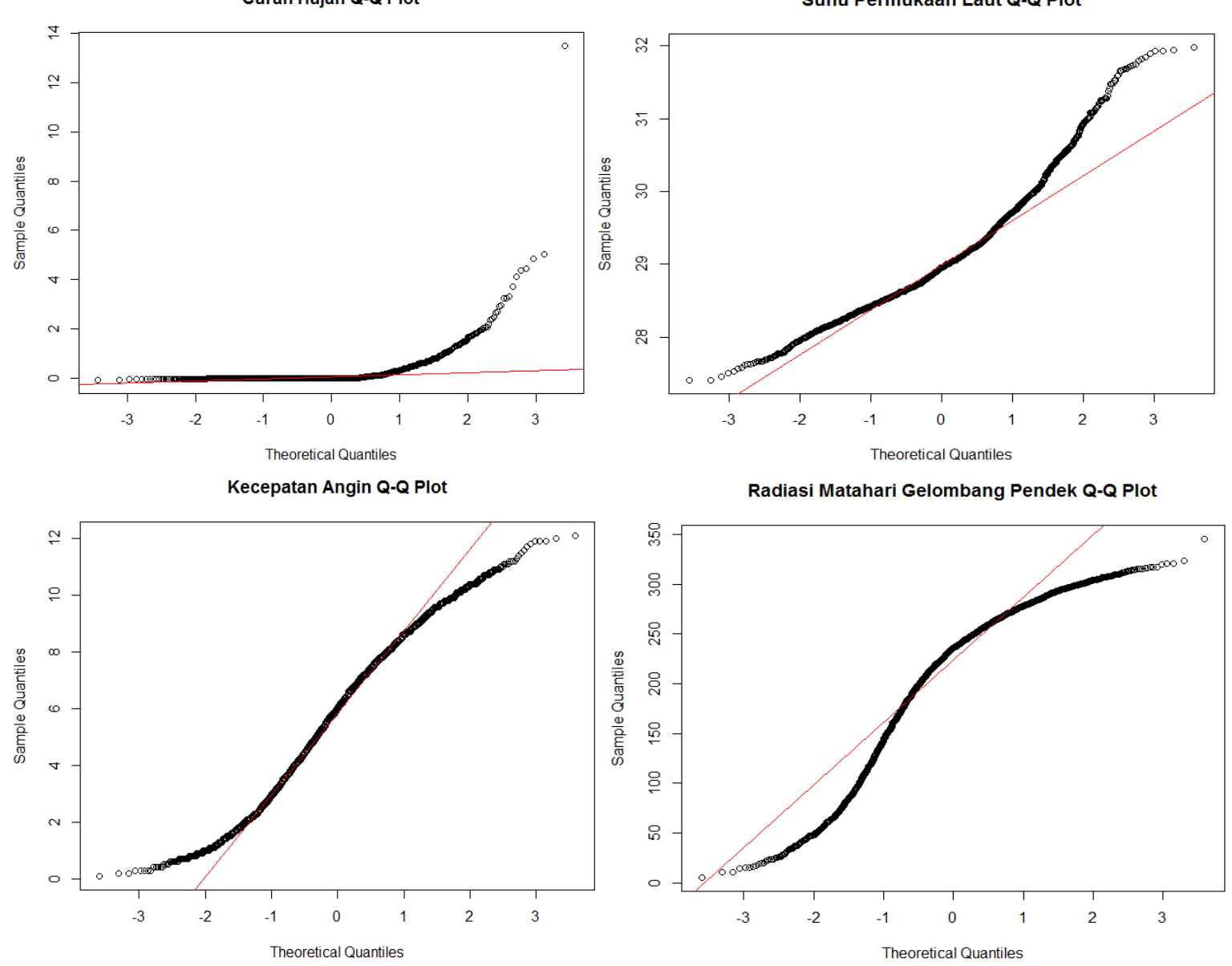


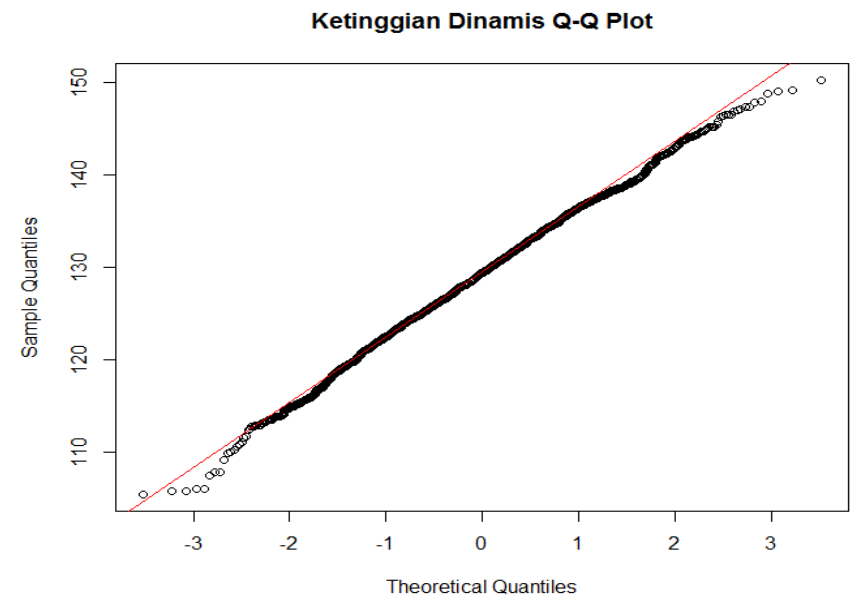

Gambar 3. Q-Q Plot dari variabel observasi

Dari Gambar 3, kemencengan qq-plot nampak bahwa masing-masing variabel memiliki pencilan dan bentuk kemencengan yang bervariasi setiap variabel. Penggunaan korelasi Pearson adalah untuk mengukur hubungan linier antara dua variabel acak kontinu. Pada korelasi ini tidak menganggap normalitas meskipun mengasumsikan adanya varian terbatas dan kovarians terbatas. Oleh karena itu, ketika kondisi variabel bivariat normal, korelasi Pearson memberikan deskripsi lengkap tentang hubungan tersebut.

\subsection{Korelasi Pearson}

Apabila suatu hubungan bernilai tidak sama dengan 0, maka dapat dikatakan terjadi hubungan antar variabel. Bagaimana hubungan tersebut, perhatikan baris-baris nilai Pearson Correlation pada Tabel 5 dan 6 berikut ini:

Tabel 5 Koefisien Korelasi Pearson with Gap Dataset

\begin{tabular}{|c|c|c|c|c|c|c|c|c|c|}
\hline \multicolumn{2}{|c|}{$\begin{array}{c}\text { Korelasi } \\
\text { Positif }\end{array}$} & \multirow{2}{*}{$\begin{array}{l}\text { Besaran } \\
\text { Korelasi } \\
\text { Kuat }\end{array}$} & \multirow{2}{*}{$\frac{\text { p-value }}{<2.2 \mathrm{e}-16}$} & \multirow{2}{*}{$\frac{\mathbf{9 5 \%} \mathbf{C I}}{(0.65,0.69)}$} & \multicolumn{2}{|c|}{$\begin{array}{c}\text { Korelasi } \\
\text { Negatif }\end{array}$} & \multirow{2}{*}{$\begin{array}{l}\text { Besaran } \\
\text { Korelasi } \\
\text { Sedang }\end{array}$} & \multirow{2}{*}{$\frac{\text { p-value }}{<2.2 \mathrm{e}-16}$} & \multirow{2}{*}{$\frac{\mathbf{9 5 \%} \mathbf{C I}}{(-0.521,-0.466)}$} \\
\hline $\mathrm{X}_{1}-\mathrm{X}_{3}$ & 0.67 & & & & $\mathrm{Y}-\mathrm{X}_{5}$ & -0.49 & & & \\
\hline $\mathrm{X}_{1}-\mathrm{X}_{5}$ & 0.43 & Sedang & $<2.2 \mathrm{e}-16$ & $(0.39,0.46)$ & $\mathrm{X}_{2}-\mathrm{X}_{5}$ & -0.43 & Sedang & $<2.2 \mathrm{e}-16$ & $(-0.471,-0.389)$ \\
\hline $\mathrm{Y}-\mathrm{X}_{2}$ & 0.38 & Rendah & $<2.2 \mathrm{e}-16$ & $(0.34,0.42)$ & $X_{3}-X_{4}$ & $-0,39$ & Rendah & $<2.2 \mathrm{e}-16$ & $(-0.427,-0.364)$ \\
\hline $\mathrm{Y}-\mathrm{X}_{4}$ & 0.31 & Rendah & $<2.2 \mathrm{e}-16$ & $(0.27,0,34)$ & $\mathrm{X}_{2}-\mathrm{X}_{1}$ & -0.35 & Rendah & $<2.2 \mathrm{e}-16$ & $(-0.394,-0.309)$ \\
\hline $\mathrm{X}_{4}-\mathrm{X}_{6}$ & 0.27 & Rendah & $<2.2 \mathrm{e}-16$ & $(0.24,0.31)$ & $\mathrm{Y}-\mathrm{X}_{3}$ & -0.25 & Rendah & $<2.2 \mathrm{e}-16$ & $(-0.285,-0.212)$ \\
\hline $\mathrm{X}_{3}-\mathrm{X}_{5}$ & 0.23 & Rendah & $<2.2 \mathrm{e}-16$ & $(0.193,0.265)$ & $Y-X_{1}$ & -0.23 & Rendah & $<2.2 \mathrm{e}-16$ & $(-0.265,-0.198)$ \\
\hline $\mathrm{Y}-\mathrm{X}_{6}$ & 0.16 & Sangat Rendah & $1.90 \mathrm{e}-14$ & $(0.12,0.21)$ & $\mathrm{X}_{3}-\mathrm{X}_{6}$ & -0.22 & Rendah & $<2.2 \mathrm{e}-16$ & $(-0.256,-0.175)$ \\
\hline $\mathrm{X}_{1}-\mathrm{X}_{4}$ & 0.12 & Sangat Rendah & $3.21 \mathrm{e}-12$ & $(0.09,0.16)$ & $\mathrm{X}_{4}-\mathrm{X}_{5}$ & -0.15 & Sangat rendah & $<2.2 \mathrm{e}-16$ & $(-0.181,-0.112)$ \\
\hline \multirow[t]{4}{*}{$\mathrm{X}_{2}-\mathrm{X}_{6}$} & 0.05 & Sangat Rendah & 0.06024 & $(-0.002,0.098)$ & $\mathrm{X}_{5}-\mathrm{X}_{6}$ & -0.11 & Sangat rendah & $1.878 \mathrm{e}-07$ & $(-0.149,-0.068)$ \\
\hline & & & & & $\mathrm{X}_{2}-\mathrm{X}_{3}$ & -0.10 & Sangat rendah & 0.0001344 & $(-0.153,-0.049)$ \\
\hline & & & & & $\mathrm{X}_{1}-\mathrm{X}_{6}$ & -0.07 & Sangat rendah & 0.0006021 & $(-0.113,-0.031)$ \\
\hline & & & & & $X_{2}-X_{4}$ & -0.03 & Sangat rendah & 0.2244000 & $(-0.081,0.019)$ \\
\hline
\end{tabular}

Tabel 6 Koefisien Korelasi Pearson tanpa Gap Dataset

\begin{tabular}{|c|c|c|c|c|c|c|c|c|c|}
\hline \multirow{2}{*}{\multicolumn{2}{|c|}{$\begin{array}{c}\text { Korelasi } \\
\text { Positif }\end{array}$}} & Besaran & & & \multicolumn{2}{|c|}{ Korelasi } & \multicolumn{3}{|l|}{ Besaran } \\
\hline & & Korelasi & p-value & $95 \% \mathrm{CI}$ & \multicolumn{2}{|c|}{ Negatif } & Korelasi & p-value & $95 \% \mathrm{CI}$ \\
\hline $\mathrm{X}_{1}-\mathrm{X}_{3}$ & 0.769 & Kuat & $<2.2 \mathrm{e}-16$ & $(0.745,0,792)$ & $\mathrm{Y}-\mathrm{X}_{5}$ & -0.542 & Sedang & $<2.2 \mathrm{e}-16$ & $(-0.581,-0.501)$ \\
\hline$X_{1}-X_{5}$ & 0.460 & Sedang & $<2.2 \mathrm{e}-16$ & $(0.414,0.504)$ & $\mathrm{X}_{2}-\mathrm{X}_{5}$ & -0.429 & Sedang & $<2.2 \mathrm{e}-16$ & $(-0.474,-0.382)$ \\
\hline $\mathrm{Y}-\mathrm{X}_{2}$ & 0.404 & Rendah & $<2.2 \mathrm{e}-16$ & $(0.355,0.450)$ & $X_{3}-X_{4}$ & -0.413 & Sedang & $<2.2 \mathrm{e}-16$ & $(-0.458,-0.364)$ \\
\hline $\mathrm{Y}-\mathrm{X}_{4}$ & 0.312 & Rendah & $<2.2 \mathrm{e}-16$ & $(0.260,0.363)$ & $\mathrm{X}_{2}-\mathrm{X}_{1}$ & -0.373 & Rendah & $<2.2 \mathrm{e}-16$ & $(-0.421,-0.323)$ \\
\hline $\mathrm{X}_{3}-\mathrm{X}_{5}$ & 0.266 & Rendah & $<2.2 \mathrm{e}-16$ & $(0.213,0.318)$ & $\mathrm{Y}-\mathrm{X}_{1}$ & -0.264 & Rendah & $<2.2 \mathrm{e}-16$ & $(-0.315,-0.210)$ \\
\hline $\mathrm{X}_{4}-\mathrm{X}_{6}$ & 0.170 & Sangat Rendah & $2.58 \mathrm{e}-09$ & $(0.116,0.226)$ & $\mathrm{Y}-\mathrm{X}_{3}$ & -0.261 & Rendah & $<2.2 \mathrm{e}-16$ & $(-0.313,-0.207)$ \\
\hline $\mathrm{Y}-\mathrm{X}_{6}$ & 0.141 & Sangat Rendah & $9.28 \mathrm{e}-07$ & $(0.085,0.196)$ & $\mathrm{X}_{3}-\mathrm{X}_{6}$ & -0.179 & Sangat rendah & $4.013 \mathrm{e}-10$ & $(-0.234,-0.124)$ \\
\hline $\mathrm{X}_{2}-\mathrm{X}_{6}$ & 0.051 & Sangat rendah & 0.07857 & $(-0.0058,0.107)$ & $\mathrm{X}_{4}-\mathrm{X}_{5}$ & -0.171 & Sangat rendah & $2.757 \mathrm{e}-09$ & $(-0.225-0.115)$ \\
\hline \multirow[t]{4}{*}{$X_{1}-X_{4}$} & 0.017 & Sangat Rendah & 0.5482 & $(-0.039,0.074)$ & $\mathrm{X}_{1}-\mathrm{X}_{6}$ & -0.137 & Sangat rendah & $<2.2 \mathrm{e}-16$ & $(-0.192,-0.081)$ \\
\hline & & & & & $\mathrm{X}_{5}-\mathrm{X}_{6}$ & -0.133 & Sangat rendah & $3.754 \mathrm{e}-06$ & $(-0.188-0.077)$ \\
\hline & & & & & $\mathrm{X}_{2}-\mathrm{X}_{3}$ & -0.106 & Sangat rendah & 0.0002416 & $(-0.162,-0.049)$ \\
\hline & & & & & $X_{2}-X_{4}$ & -0.013 & Sangat rendah & 0.6633 & $(-0.069,0.044)$ \\
\hline
\end{tabular}

Berdasarkan Tabel 5 diketahui bahwa hasil pada pengujian korelasi pearson sama dengan hasil pada scatterplot matriks, yang dimana pada scatterplot matriks merupakan korelasi pearson dalam bentuk visual. Namun 
secara inferensia hasil pada kedua tersebut sama yaitu variabel $\mathrm{X}_{1}$ (suhu udara) dan $\mathrm{X}_{3}$ (suhu permukaan laut) memiliki hubungan keeratan tertinggi dibandingkan dengan variabel lainnya, baik itu secara hubungan antara variabel respon dengan variabel bebas, maupun secara keseluruhan dengan nilai korelasi positif sebesar 0.769. Kemudian untuk nilai korelasi terendah berada pada $\mathrm{X}_{2}$ (curah hujan) dan $\mathrm{X}_{4}$ (kecepatan angin) dengan nilai korelasi negatif sebesar -0.01. Pada gambar juga terdapat beberapa variabel yang berpola linier dan berkorelasi kuat positif yaitu variabel $\mathrm{X}_{1}$ dan $\mathrm{X}_{5}$, variabel $\mathrm{Y}$ dan $\mathrm{X}_{2}$ dengan nilai korelasi berturut-turut adalah sebesar 0.46 dan 0.40. Hal ini berarti semakin besar $\mathrm{X}_{2}$ (suhu udara) maka semakin besar $\mathrm{X}_{5}$ (radiasi matahari gelombang pendek) begitu juga semakin besar $\mathrm{Y}$ (kelembaban relatif) maka semakin besar $\mathrm{X}_{2}$ (curah hujan). Selain itu, terdapat juga variabel yang berkorelasi kuat negatif yaitu variabel $\mathrm{Y}$ dan $\mathrm{X}_{5}, \mathrm{X}_{2}$ dan $\mathrm{X}_{5}, \mathrm{X}_{3}$ dan $\mathrm{X}_{4}$ dengan nilai korelasi berturut-turut sebesar -0.54, -0.43 dan -0.41 . Hal ini berarti bahwa semakin besar $Y$ (kelembaban relatif) maka semakin rendah $\mathrm{X}_{5}$ (radiasi matahari) begitu juga dengan $\mathrm{X}_{2}$ (curah hujan) dan $\mathrm{X}_{5}$ (radiasi matahari gelombang pendek) serta $\mathrm{X}_{3}$ (suhu permukaan laut) dan $\mathrm{X}_{4}$ (kecepatan angin). Kemudian untuk korelasi lainnya dapat dilihat pada Table 5 .

Bila kita bandingkan besaran korelasi Pearson dari Tabel 5 dan 6 adalah nilai korelasi dengan gap memiliki kecenderungan memiliki nilai koefisien korelasi lebih rendah dibandingkan nilai korelasi tanpa gap dalam dataset untuk korelasi positif. Sedangkan untuk korelasi negatif berlaku sebaliknya,. Adanya gap dapat mempengaruhi pola distribusi, bentuk dan kemencengan distribusi data sehingga mempengaruhi besaran korelasi dan arah (positif atau negatif)

\section{Kesimpulan}

Pada penelitian ini, hubungan keeratan tertinggi adalah variabel suhu udara dan suhu permukaan laut dengan nilai korelasi positif sebesar 0.769. Sedangkan hubungan keeratan terendah yaitu variabel curah hujan dan kecepatan angin dengan nilai korelasi lemah negatif sebesar -0.01. Korelasi menunjukkan bahwa adanya gap dalam dataset menurunkan nilai besaran korelasi positif, meskipun kekuatan hubungan masih dalam range yang sama, dibandingkan korelasi tanpa gap dalam dataset observasi. Hal ini berlaku sebaliknya keberadaan gap pada hubungan antar variabel untuk korelasi negatif. Pada penelitian selanjutnya dapat menggunakan metode imputasi data agar data yang digunakan menjadi data complete (tanpa data hilang). Sehingga diharapkan hasil yang didapatkan menjadi lebih signifikan keeratan hubungan antar variabelnya.

\section{Ucapan Terima Kasih}

Tim peneliti menyampaikan terima kasih kepada Jurusan Statistika FMIPA Unsyiah dan Direktorat Riset dan Pengabdian pada Masyarakat (DRPM) Ristekdikti, Kementerian Pendidikan dan Kebudayaan Indonesia dalam program pengabdian usaha pengembangan intelektual kampus (PPUPIK), Jakarta. 2020.

\section{Daftar Pustaka:}

[1] Saji, N. H., Goswami, B. N., Vinayachandran, P. N., \& Yamagata, T. 1999. A Dipole Mode In the Tropical Indian Ocean. Nature, 401(6751), 360-363.

[2] Aldrian, E. 2008. Meteorologi Laut di Indonesia. Badan Meteorologi dan Geofisika, Jakarta.

[3] Miftahuddin, 2006, Wavelet Morlet dalam Estimasi ENSO, Jurnal Natural FMIPA Universitas Syiah Kuala, Aceh, Vol.6, pp 27-33, ISSN: 1141-8513.

[4] Miftahuddin, 2007, Kajian ENSO dalam Regresi Linier Berganda, AR(1), dan RM 2-State, Jurnal Natural FMIPA Universitas Syiah Kuala, Aceh, Vol.7 , pp 26-35, ISSN 1141-8513.

[5] Miftahuddin, Andriani, Ria, Setiawan, Ichsan dan Mulsandi, Adi. 2013, Penerapan Analisis Korelasi Kanonik pada Kajian ESO dalam Identifikasi Hubungan Fitur Iklim, Jurnal Natur Indonesia, 15, 36-44, ISSN: 1410-9379.

[6] Schott, Friedrich A. Xie, Shang-Ping and McCreary Jr., Julian P. 2009. Indian Ocean Circulation and Climate Variablility. Reviews of Geophysics, 47, RG1002. American Geophysical Union.

[7] IPCC. 2007. Climate Change 2007: Impacts, Adaptation and Vulnerability. Contribution of Working Group II to the Fourth Assessment Report of the Intergovernmental Panel on Climate Change, M.L. Parry, O.F. Canziani, J.P.Palutikof, P.J. van der Linden and C.E.Hanson (Eds). Cambridge, UK:Cambridge University Press.

[8] IPCC, 2020. The IPCC and the sixth Assessment Cycle.

[9] Michael J de Smith. 2018. Statistical Analysis Handbook A Comprehensive Handbook of Statistical Concepts, Techniques and Software Tools. The Winchelsea Press, Drumlin Security Ltd, Edinburgh

[10] Conover, W. J. 1971. Practical Nonparametric Statistics. John Wiley \& Sons, Inc. 